\title{
The Plot against Cancer: Heredity and Cancer in German and Dutch Medicine, 1933-1945
}

Stephen Snelders

\section{Summary}

In the Third Reich hereditarian approaches and their eugenic implications seemed to offer possibilities for fundamental progress in the fight against cancer. This did not lead to an exclusive emphasis on genetics in theory or practice. The concept of a hereditary predisposition for cancer, the Krebsdisposition or Krebsbereitschaft, led to flexible multifactor approaches, including proposals for both eugenic and social-hygienic measures. These approaches were not typical of German medicine alone. In the Netherlands hereditarian approaches did not play a central role in the 1930s. They lacked institutional support in a country where health policies were characterised by indirect strategies working through intermediaries such as general practitioners and home nursing organisations. However, potentially the elements for similar anti-cancer policies as in Germany were present. The German occupation offered opportunities to develop these elements (concepts, institutions, personnel). This development was blocked because of the political radicalisation during the war and the German defeat.

Keywords: genetics; eugenics; cancer; National Socialist Germany; the Netherlands

\section{Introduction}

In our practices around and representations of cancer heredity has made a spectacular comeback since the early 1990s. Individuals are confronted with evidence that cancer runs in their families and have to make far-reaching decisions. After decades in which heredity of cancer and cancer families were

Stephen Snelders, VU-University Medical Centre, Department of Metamedica (Medical Humanities), k. D-326, PO Box 7057, NL-1007 MB Amsterdam (s.snelders@vumc.nl). 
relegated to a secondary role in research, diagnosis and treatment, and were hardly even spoken of in the public sphere, genetic medicine once again raises the fears of genetic determinism ${ }^{1}$. This is not the first time that hereditarian approaches seem to offer hopes of victory in the fight against cancer. In the decade before and during the Second World War these hopes and their consequences for practices of treatment and prevention were widely debated in medicine. This article will take a closer look at these debates and their possible consequences for anti-cancer policies by giving comparative examples and impressions from two countries, each with a different political context: National Socialist Germany and the Netherlands at the eve of and during the German occupation in the Second World War.

What makes these specific cases of interest? On the European continent German medicine stood in the vanguard of the fight against cancer. Not only did German cancer researchers discuss and explore the consequences of a hereditarian approach, but within the context of National Socialist public health policies there were opportunities to put their ideas into practice ${ }^{2}$. In this, hereditarian approaches were regarded as complementary to environmental approaches. With a nod to Philip Roth's best-selling novel The Plot Against America (2004) I have called these complementary approaches the 'Plot against Cancer'. Just as the plot of Hermann Goering and Charles Lindbergh to create a National Socialist America was not actually realised in history, the 'plot' of German scientists and doctors to win the war against cancer was never realised, partly because of the coming of another, even more devastating war in 1939-1945. As Adolf Hitler in 1940 told Kurt Blome, who would become the "Reichsbevollmächtigter für Krebsforschung", the fight against cancer had to wait until after the war'.

In the democratic Netherlands in the 1930s hereditarian approaches at first glance did not enter health policies, though German medicine was a major influence on Dutch medicine. But a closer look at the ideas of Dutch scientists and doctors makes it clear that here too the elements for a 'Plot against Cancer' were present. A comparison will enable us to speculate about the political and social conditions necessary for the incorporation of hereditarian approaches in public health and anti-cancer policies.

1 For a more extensive discussion of these historical and contemporary developments around cancer and genetics, with a focus on the Netherlands, cf. Krabben/Pieters/Snelders 2007; Snelders/Pieters/Meijman 2007.

2 Moser 2005; Moser 2006a; Moser 2006b; Proctor 1999; Wagner/Mauerberger 1989; Woitke 1993.

3 Moser 2006a, 134. 


\title{
German medicine and the heredity of cancer
}

In 1928 cancer succeeded tuberculosis as the second most frequent cause of mortality in Germany, after coronary heart disease. In the Third Reich cancer health policies changed direction from an emphasis on treatment towards prevention. Early detection and population screening were stimulated ${ }^{4}$. How did heredity fit into this?

The influential textbook on human genetics by Erwin Bauer, Eugen Fischer and Fritz Lenz, Grundriss der menschlichen Erblichkeitslehre und Rassenhygiene, had in the 1920s rejected monocausal explanations of cancer. However, the authors claimed that a hereditary predisposition could play a role in the aetiology of a number of cancers, and especially stomach cancer ${ }^{5}$. In general, cancer was seen by German doctors in the interwar period as a constitutional disease, in which multiple factors were involved; heredity, diet, stress, industrial pollution and racial factors could all play a part ${ }^{6}$. Only a few rare cancers such as neuroblastoma (an eye cancer) and intestine cancer had proven to be simply transmitted by a dominant Mendelian factor ${ }^{7}$.

Opinions on the exact role of heredity were by no means monolithic in the Third Reich. The surgeon Karl Heinrich Bauer (1890-1978), professor in Breslau and after the war founder of the German Cancer Institute, was in general an adherent of the mutation theory: environmental influences, e.g. radiation, damaged the chromosomes causing the growth of malignant tumours ${ }^{8}$. He was the author of the section on cancer for the influential series of textbooks edited by NSDAP member Günther Just (1892-1950) and published in and around 1940, the Handbuch der Erbbiologie des Menschen ${ }^{9}$. Bauer did not assign a very important role to a Krebsdisposition, or Krebsbereitschaft or Krebsanlage as it was also called, though he did not deny its role in the aetiology of cancers. To him, even in cases of hereditary predisposition cancer could be prevented and cured: it was, after all, the price we had to pay for life extension and civilisation, and not an unavoidable biological mechanism ${ }^{10}$.

Other German cancer researchers regarded the role to heredity as more important. One of the foremost among them was Bernhard Fischer-Wasels (1877-1941). He was in 1931 director of the pathological institute and rector

\author{
4 Proctor 1999; Woitke 1993. \\ 5 Bauer/Fischer/Lenz 1927, 324. \\ 6 Proctor 1999, 127. \\ 7 Auler 1937, 393f.; Fischer-Wasels 1935, 93. \\ 8 Proctor 1999, 63f. \\ 9 For Just, cf. Klee 2007, $293 f$. \\ 10 Bauer 1940.
}


of the University of Frankfurt am Main when he claimed that it was beyond doubt that cancer families existed, families in which the predisposition to cancer was inherited. To him American cancer researcher Maud Slye had proven the Mendelian inheritability of cancer tumours in her investigations of the inheritability of cancer in mice in the 1920s. Only the mechanism of this inheritability was still unclear. The predisposition for cancer could be inherited or acquired, without coming to the actual expression of the disease in one's lifetime; and the disposition could again be inherited by one's descendants ${ }^{11}$.

Die Geschwulstbildung entsteht hier aus einer lokalen Regeneration, sobald die Allgemeindisposition des Körpers gegeben, d.h. erblich festgelegt oder künstlich durch Gifte erzeugt, ist. $^{12}$

As Fischer-Wasels continued to explain in publications and lectures after 1933, for cancer to occur the general factor, die allgemeine Krebsdisposition, had to come together with a local factor. This local factor too could be inherited (e.g. polyposis intestini, intestine polyps, that could develop into cancerous tumours) or it could be acquired (e.g. by skin irritation). In this view local methods of treatment (surgery, radiation) had to be combined with general methods of prevention: die Aufgabe einer Bekämpfung der allgemeinen Disposition des Körpers ${ }^{13}$.

It was Fischer-Wasels's hope that progress in the knowledge of the heredity of cancer should lead to the development of successful prevention policies. He therefore made a plea for post-mortem examination of people who had died of cancer and for the creation of a database of all people and families with cancer, a menschliches Krebsarchiv. Though he admitted that establishing the laws of the heredity of cancer would be difficult ${ }^{14}$.

The Swiss researchers Hans Schinz and Franz Buschke took a slightly different approach in their German-language textbook Krebs und Vererbung ('Cancer and Heredity'), published in 1935, in which they tried to delineate the extent of the influence of heredity on cancer. The authors addressed fundamental questions about the clinical relevance of knowledge around cancer and heredity. Most basic was the question of how to recognise the carrier of a predisposition for cancer before the disease manifested itself. This would have distinct advantages, because then the physician could act, for instance by manipulating the environment in such a way that the disposition would

11 Fischer-Wasels 1931.

12 Fischer-Wasels 1931, 64.

13 Haubold 1936, 530.

14 Fischer-Wasels 1931, 65. 
not come to actual expression. Here, in the expression of the phenotype, and not in the manipulation of the genotype, was medical intervention possible.

Recognition of a cancer predisposition could in individual cases, and to a certain degree, be done by the well-established method of pedigree research. However, Schinz and Buschke acknowledged that this method only gave reliable evidence in cases of very strong hereditary taints; this because of the very complex ways in which cancers come to expression. The authors proposed a different method; research into correlations between cancer disposition and other hereditary characteristics embodied in genes on the same chromosomes; research of morphological and serological variations; and research of functional characteristics. Once recognition of cancerous predispositions would be possible to a more reliable degree than pedigree research allowed for, new opportunities in the fields of prevention as well as diagnosis were created according to these authors. Periodic diagnostic tests of people with a higher risk factor (Gefährdeten) would substantially improve prognosis for treatment and recovery. Individual prophylaxis could be directed against avoidable stimulations from the environment that determined the expression of cancer dispositions, such as tobacco and dental infections. And improved diagnosis of 'pre-cancerous' symptoms that might or might not point to the development of malignant tumours became possible if the hereditary predisposition could be taken into account ${ }^{15}$.

Berlin professor Hans Auler, of the Reichsausschuss für Krebsbekämpfung (the Reich Anti-Cancer Committee), explained in 1941 that research would establish correlations between constitutional types and the prevalence of cancer. Racial characteristics such as skin colour and pigmentation seemed to be of importance here. This could for instance explain the difference in the prevalence of breast cancer among European and Japanese women ${ }^{16}$.

By this time German cancer researchers expressed far-going views on the importance of heredity in coping with cancer. Just before his death in 1941 Fischer-Wasels wrote that, despite the fact that we still knew very little about hereditary factors in cancer, all elements necessary for the expression of the disease could lie in the genetic make-up, the Erbmasse ${ }^{17}$. Regierungsrat and SS-officer Helmut Haubold (1905-1968) of the Reichsgesundheitsamt (he would make it to the rank of SS-Obersturmbannführer, or Major) stated in 1939 that German and international research showed that constitution and hereditary factors (Konstitution und Erbfaktoren) played the most important role in cancer.

15 Schinz/Buschke 1935.

16 Auler 1937,395f.

17 Fischer-Wasels 1941, 16. 
Wenn trotz aller Umschichtungen in der Bevölkerung von zehn Grossstädten mit insgesamt 9,4 Millionen Einwohnern und trotz einer starken Zunahme der absoluten Krebstotenzahlen die Krebssterblichkeit gleich bleibt oder absinkt, so haben anscheinend äussere Einflüsse nur geringen Einfluss auf diesen biologischen Prozess im Volkskörper. Die Konstitution und der Erbfaktor scheinen demnach für das Auftreten von Massenkrebsen von entscheidender Bedeutung zu sein! $!^{18}$

Though the war limited resources for cancer research, heredity continued to be of interest. One of the defendants at the Nuremberg medical trials, Kurt Blome (1894-1969), accused of experiments on humans and appointed Bevollmächtigter für Krebsforschung by Goering in 1943, claimed that one of his research themes had been the heredity of cancer ${ }^{19}$. Characteristics of cancer research remained constant up to the end of the war, even though in Blome's case cancer research was linked to research in biological and chemical warfare ${ }^{20}$.

\section{Eugenics and cancer}

In the focus on heredity the fate of the individual patient and the work of the individual doctor were connected to the collective project of a healthy racial state. In 1941 Auler advised physicians on taking an anamnesis to ask as first question whether cancer had occurred in the family. 'Bei Krebshäufigkeit besondere Vorsicht! ${ }^{21}$ Doctors would focus their attention on the families, the Sippengemeinschaften of their patients, as Haubold put it in the same year. Data would be collected that would help solve the problem of the aetiology of cancer. From now on the individual was no longer the focus of medical care.

Der Arzt [...] wird vielmehr jeden Krebsverdächtigen als Glied einer mehr oder weniger krebsgefährdeten Familie ansehen lernen..$^{22}$

German researchers did not hesitate to speculate about possible eugenic consequences of their findings. Fischer-Wasels was full of hope that progress in knowledge would lead to an anti-cancer eugenics or cancer prophylaxis ${ }^{23}$. In 1931 his hope had been centred on an appeal to cancer families to voluntarily restrain themselves from reproduction ${ }^{24}$. Prof. Dr. H. Poll, director of the anatomical institute in Hamburg, differentiated at the time between

18 Haubold 1939, 310. For Haubold, cf. Klee 2007, 232.

19 Weindling 2004, 153.

20 Moser 2005; Moser 2006a; Moser 2006b.

21 Auler 1941a, 36.

22 Haubold 1941, 246.

23 Fischer-Wasels 1934a; Fischer-Wasels 1935.

24 Fischer-Wasels 1931. 
the Nahziel, the nearest objective, being the treatment of individual cancer patients, and the farther objective of a Genotherapie:

Diese besteht einerseits in einer sinnvollen Erbauslese, andererseits in dem heroischen Entschluss aller Krebsbelasteten, die heimtückisch im Blut der Generationen kreisenden Anlage durch Nichtvermehrung zum Erlöschen zu bringen. ${ }^{25}$

From 1933 on, more far-reaching possibilities came in sight. In 1933 the Gesetz zur Verhütung erbkranken Nachwuchses made the involuntary sterilisation of carriers of hereditary diseases possible. In 1935 the Gesetz zum Schutz der Erbgesundheit des deutschen Volkes made a hereditary health certificate mandatory before marriage ${ }^{26}$. It is true that the 1933 sterilisation law did not specifically mention hereditary cancer as a ground for Sterilisierungsverpflichtung, the legal obligation to be sterilised. However, the 1936 commentaries on the law did open up the possibility of sterilisation in the case of diseases such as tumours leading to hereditary blindness, which includes neuroblastoma; though the commentaries did not give a catalogue of these diseases ${ }^{27}$. There is no evidence that the Hereditary Health Courts, the Erbgesundheitsgerichte, of the Third Reich actually did order sterilisation in cases of cancer ${ }^{28}$. Nevertheless, there is no reason why they should have refrained from it in the long run. As early as 1935 Fischer-Wasels advocated sterilisation in cases of neuroblastoma ${ }^{29}$. His plea for marriage counselling and a negative advice for those who both had parents with cancer (for instance stomach cancer) stroke responsive chords among his colleagues ${ }^{30}$.

However, the appeal of hereditarian approaches in the prevention of cancer went further than pleas for these kinds of eugenic policies. Since in the overwhelming majority of cancers not genetic determinism but the concept of the disposition stood central, there were more ways to crack an egg. Eugenic hopes were not limited to the effects of sterilisation or marriage counselling; indeed, it was considered much more effective to manipulate the Krebsbereitschaft by manipulating environmental factors. In 1935 FischerWasels, in a book addressed to a more general audience, emphasised again that exterior circumstances were needed for the expression of die allgemeine Krebsbereitschaft. It was not only heredity that should be controlled; harmful environmental influences should be eliminated as well. For treatment early detection was still of the utmost importance; health communication directed towards the whole population as well as towards specific groups

25 Fischer-Wasels 1931, xii.

26 Cf. Proctor 1988.

27 Gütt/Rüdin/Ruttke 1936, 148f.

28 Proctor 1988, especially p. 108.

29 Fischer-Wasels 1935, 92f.; Fischer-Wasels 1941, 30.

30 Auler 1937, 394f.; Fischer-Wasels 1941, 30. 
(doctors, dentists, nurses) and periodic examination of the population were essential. In this way Fischer-Wasels combined a hereditarian approach with the message of Do Not Delay, the necessity of the early diagnosis of symptoms. This message went hand in hand with the idea that the development of the cancerous predisposition should be prevented by a multifactor approach: by Erbbiologische Verhütung der Krebskrankheit, i.e. marriage counselling to prevent the birth of children with a hereditary predisposition, by protective working conditions and by the strengthening of the constitution through gymnastics, better diet and other improvements in lifestyle ${ }^{31}$. Fischer-Wasels advocated therefore not only eugenische Prophylaxe but also Konstitutionspflege $^{32}$. There were so many environmental factors that could be manipulated that doctors felt no need for pessimism in the field of prevention at all ${ }^{33}$. Though not inspired by National Socialist ideas, the ideas of the cancer research fitted therefore easily into National Socialist cancer health policies. These emphasised not only early detection, but also prevention by banning carcinogenic substances and advocating healthy living and non-smoking ${ }^{34}$. Here as elsewhere German medicine was not a docile follower of Nazi policies but had its own agenda that could be strengthened by state policies in the Third Reich ${ }^{35}$. Though in practice implementation and effects of these policies were rather complicated and though they were only meant for racially pure Germans, they offered German doctors the prospect of total victory in the war against cancer.

\section{The Netherlands in a Nazi Nebenwelt}

While eugenic proposals were met with positive reactions in the political climate of the Third Reich, this was far less the case in its western neighbour the Netherlands. Historical accounts have minimised the importance of heredity in Dutch health policies because of the limited strength of the Dutch eugenic movement ${ }^{36}$. Nevertheless, elements for a 'Plot against Cancer' were here present as well: a plot based on the concept of a hereditary predisposition for cancer, aiming to fight cancer by means of birth control and socialhygienic measures.

31 Fischer-Wasels 1935; cf. also Fischer-Wasels 1934a.

32 Fischer-Wasels 1935, $92 \mathrm{f}$.

33 Fischer-Wasels 1935, 85-93.

34 Cf. Proctor 1999.

35 Cf. Evans 2006, 444-446.

36 Noordman 1989. For Dutch eugenics, cf. also Snelders 2007; Snelders 2008; Snelders/Pieters 2003, $211 f$. 
Consider the following historical data that together could have laid the foundation for an alternative history of Dutch health policies. Reinder van Calcar (1872-1957) was professor of hygiene and 'medical police' at the University of Leiden. A cancer specialist, he was also convinced of the reality of racial degeneration in his society. Following the 'evidence' as presented by Eugen Fischer, the director of the Kaiser-Wilhelm-Institut für Anthropologie, menschliche Erblehre und Eugenik in Berlin-Dahlem, Van Calcar perceived this racial degeneration as leading to a declining birth rate in general; but at the same time it would lead to a higher birth rate among the mentally deficient. Van Calcar was also obsessed with the idea that racial degeneration expressed itself in a growing dependence on what he called 'mental narcotics' (psychische verdoovingsmiddelen), by which he not only meant drugs such as barbiturates and cocaine but also the theatre, the cinema and sport matches. At the same time, Van Calcar rejected compulsory sterilisation on the German model, partly because Mendel's laws of heredity could not predict with certainty individual outcomes of the mixing of genes. Still, he considered it the duty of citizens to produce a healthy progeny ${ }^{37}$. Van Calcar related his thoughts on racial degeneration to his research interest cancer. In 1937 he claimed that not cancer itself was on the increase, but the hereditary predisposition for the disease. The primary cause was the deterioration in the mental state of the population, which so weakened the individual that the cancers could come to expression. This could therefore not be solved by birth control measures. Measures in the field of social hygiene, especially directed to the stimulation of healthy lifestyles in families, were needed to prevent phenotypes developing according to (cancerous) genotypes ${ }^{38}$.

Van Calcar does not figure in any account of the Dutch eugenic movement. His example shows, however, that eugenic thought, obsessions with racial degeneration and pleas for social measures to improve the hereditary constitution of the Dutch 'race' or population were more general among the Dutch intellectual elite than is often assumed. This kind of thinking, and at least the concept of hereditary predisposition, was certainly present among Dutch cancer researchers in the 1930s. Van Calcar, who at one point was still partial to the theory that cancer was caused by parasites, might not have been in the vanguard of medical research ${ }^{39}$; Remmert Korteweg (1884-1961), head of the laboratory of the Antoni van Leeuwenhoek cancer hospital in Amsterdam, definitely was. From 1933 onwards he studied the inheritability

37 Van Calcar 1933, 38-53; Van Calcar 1937, 190.

38 Van Calcar 1937, 168-191.

39 Van Calcar 1920. 
of cancer in mice along parallel lines to the research of Clarence C. Little in the United States ${ }^{40}$. This made him careful of high estimations of the role of hereditary factors in cancer. Still, he maintained that especially in breast cancer and gynaecological cancers the role of a hereditary predisposition was of the utmost importance and that prophylaxis was more important than therapy since environmental influences had to work together with hereditary ${ }^{41}$. By 1940 this idea was more or less generally accepted in Dutch medicine, though here as elsewhere it was still the question whether there existed a general cancer disposition or particular dispositions for specific cancers ${ }^{42}$.

However, contrary to the situation in Germany there was no institutional context or political support in the Netherlands for eugenic health policies. In the context of the Dutch health system before 1940 there was no prospect of institutionalising eugenic ideas or embodying them in law. Dutch health policies were characterised by indirect strategies, working through intermediaries such as the protestant, catholic, liberal and socialist insurance and home nursing societies, with a restrained role for the state ${ }^{43}$.

This changed with the coming of the war. The German occupation of 1940 seemed to offer opportunities to transform Dutch health care. It has been claimed that the medical profession in general, including the eugenic doctors, were too anti-German to wish to make use of these opportunities ${ }^{44}$. For the historian of the Dutch eugenic movement there was hardly any overlap between the Dutch eugenicists and human geneticists on the one hand, and the National Socialist 'racial hygienists' who advocated more extreme policies and worked together with the Germans on the other ${ }^{45}$. More recent research into archival and published primary sources suggests strongly that this might have been the impression the eugenicists wished to make after the war, but that the picture was more complicated; especially in the first phase of the war, before the radicalisation of anti-Jewish policies and the German defeat at Stalingrad.

An example of this complexity is the position of biologist Wouter Ströer (1907-1979) within the circle of Dutch geneticists and eugenicists ${ }^{46}$. Before the war Ströer had been a respected scientist with articles in major scientific and eugenic journals. He was a contributor to Afkomst en Toekomst (Descent and Future), the foremost eugenic journal in the Netherlands, and his article

40 Erik/Korteweg/Vos 1949, 9 ff.

41 Korteweg 1939; Korteweg 1941.

42 Wibaut 1940, 160f. Cf. Snelders/Pieters/Meijman 2007.

43 Cf. Snelders/Meijman/Pieters 2006.

44 On Dutch medicine and the German occupation: Van Lieburg/Mijnhardt 1991; Schellekens/ Visser 1987, 90-96; In 't Veld 1983; De Vries 1949.

45 Noordman 1989, 134-136.

46 For a more extensive discussion of Ströer, cf. Snelders 2007; Snelders 2008. 
on the "Heredity of normal and abnormal morphological characteristics" was part of the textbook of Dutch medical genetics, Medicine and Heredity, that was published in $1941^{47}$. This despite the fact that Ströer was a convinced National-Socialist, a known member of the Dutch SS, who enjoyed going in his black uniform to his work at the university of Groningen ${ }^{48}$. It is true that his contribution to Medicine and Heredity was published anonymously; but this was at his own request, since one of the other authors, the physician Jacob Sanders, was a Jew ${ }^{49}$. This was not a reason for the editors of the volume, M. J. Sirks, professor of genetics (erfelijkheidsleer) at the university of Groningen, and the communist psychiatrist G. W. Kastein, to dismiss Ströer's contribution altogether, despite Sirks's professed distaste for anti-Semitic policies expressed after the war. By then Kastein could not profess anything anymore, since he had committed suicide after his arrest by the Sicherheitsdienst in $1943^{50}$.

The introduction of Sirks and Kastein to Medicine and Heredity shows that eugenics at this time cut across all political boundaries. They advocated a closer attention to the hereditary fundaments and constitution of our collective and individual health, and to the prevention of the birth of hereditary tainted children ${ }^{51}$. Contributors to Afkomst en Toekomst made in the same year, 1941, pleas for a legal compulsory medical examination before marriage and suggested sterilisation as a humane alternative for segregation ${ }^{52}$. Though, still in the same year, the magazine was folded, according to one historian because the eugenicists were afraid to be associated with the Germans, documents in the post-war criminal files of Dutch SS doctors show that as late as November 1942 there were still discussions going on between Nazi and non-Nazi eugenicists ${ }^{53}$. Only when these discussions broke up, did the Germanic SS in the Netherlands (as the Dutch SS was now called) decide to set up, with the aid of the Ahnenerbe, Himmler's scientific institute, its own medical genetic infrastructure to put into practice the 'Plot Against Cancer' and other diseases ${ }^{54}$.

It is not my intention here to suggest that the Dutch eugenic movement and Dutch human genetics were on the wrong side of the fence in the

47 Anonymous 1941.

48 NIOD, documentation-Ströer; Hajema 1987; cf. also Schellekens/Visser 1987, 92-96.

49 Sirks/ Waardenburg 1949, 8.

50 De Jong 1975, 593.

51 Sirks/Kastein 1941, 9-13.

52 Frets 1941; Schrijver 1941; Bijlmer 1941; Benders 1941.

53 Noordman 1989, 127f.; NA-CABR number 24043, letter Jan van den Hoeven to Wouter Ströer, 15th November 1942.

54 Cf. Snelders 2007; Snelders 2008. For the Ahnenerbe and its involvement in the Netherlands cf. Kater 1997. 
Second World War. Interesting about this example is that it shows that as late as 1942 the situation of who was on what side was not clear at all, and that a variety of counterfactual developments were still possible. The elements (the concepts, the institutes, the personnel) were there for the integration of health policies based on the concept of a hereditary cancer predisposition into Dutch health care, in an alternative history of what SF writer Philip K. Dick has called a Nebenwelt, a world where Germany has won the war. This integration would have opted for flexible combinations of biological and psychosocial interventions. Even where theoretically the Dutch racial hygienists chose for strict formulations of genetic and racial essentialism, when it came to working this out in practical plans, genetic determinism was modified. The ophthalmologist Gerrit Schalij, leader of the Medical Front of Dutch National Socialist health care professionals, stated that care for the hereditary predisposition was the most important part of its work ${ }^{55}$. At the same time guidelines of the Medical Front pointed out that the boundaries between heredity and environment were not completely clear. Environmental influences should therefore be improved as much as possible, next to the introduction of birth control policies. Better working and living conditions, improvements in diet and clothing, and stimulation of sport were considered of as much practical importance as marriage counselling, sterilisation and measures against alcoholism, prostitution and venereal diseases ${ }^{56}$.

\section{Conclusion}

Both in German and Dutch medicine there existed in the period 1933-1945 a fertile ground on which a 'Plot against Cancer' could have developed and in time put into practice. Hereditarian and eugenic thought was spread throughout both German and Dutch medicine, across political boundaries. The Plot was eugenic in a broad sense of the word, aiming at improvement of the hereditary make-up of the population by birth control measures as well as measures of social hygiene. In our historical world the 'Plot against Cancer' did not come to pass. What ultimately was fatal to the development of the Plot was the German defeat and, in the Netherlands, the political radicalisation during the war. Nazi crimes made genetics and heredity suspect. It would take almost four decades for heredity to return in anti-cancer policies, but under very different political, social and cultural conditions. 


\section{Sources}

NA-CABR: National Archive The Hague, Centraal Archief Bijzondere Rechtspleging. NIOD: Nederlands Instituut voor Oorlogsdocumentatie, Amsterdam.

\section{Bibliography}

Anonymous, «De erfelijkheid van normale en abnormale morphologische kenmerken», in: Sirks/Kastein (1941) 75-100

Auler, Hans, «Rasse und bösartige Geschwülste», in: Johannes Schottky (Hrsg.), Rasse und Krankheit (München 1937) 388-399

- «Klinische Diagnostik der bösartigen Geschwülste. Allgemeiner Teil», in: Auler, Hans/ Heinrich Martius (Hrsg.), Diagnostik der bösartigen Geschwülste. Leitfaden für den praktischen Arzt (München 1941a) 36-42

- /Heinrich Martius (Hrsg.), Diagnostik der bösartigen Geschwülste. Leitfaden für den praktischen Arzt (München 1941b)

Bauer, Erwin/Eugen Fischer/Fritz Lenz, Grundriss der menschlichen Erblichkeitslehre und Rassenhygiene (München ${ }^{3} 1927$ )

Bauer, Karl H., «Erbanlage der Geschwülste des Menschen», in: Günther Just (Hrsg.), Handbuch der Erbbiologie des Menschen, Bd.2, Teil 2, Innere Krankheiten (Berlin 1940) 1122-1176

Benders, Albertus M., «Opmerkingen inzake geneeskundig onderzoek vóór het huwelijk», Afkomst en Toekomst 7 (1941) 349-351

Bijlmer, Hendricus J.T., «Het geneeskundig onderzoek vóór het huwelijk», Afkomst en Toekomst 7 (1941) 286-295

Calcar, Reinder P. van, De kanker en zijn ontstaan (Leiden 1920)

- Natuurkennis en levensbeschouwing. Rassenhygiène of rassendegeneratie (Leiden 1933)

- College herinneringen, Vol. 3, De kanker (Rotterdam 1937)

Erik, Petrus/Remmert Korteweg/Joseph Vos, Redevoeringen uitgesproken bij gelegenheid van de promotie van Remmert Korteweg tot doctor honoris causa in de geneeskunde 22 juni 1949 te Groningen (Groningen 1949)

Evans, Richard J., The Third Reich in Power 1933-1939 (London 2006)

Fischer-Wasels, Bernhard, Vererbung und Krebsforschung (Leipzig 1931)

- Wege zur Verhütung der Entstehung und Ausbreitung der Krebskrankheit (Berlin 1934a)

- «Die Bedeutung der besonderen Allgemeindisposition des Körpers für die Entstehung der Krebskrankheit und die Möglichkeiten ihrer Bekämpfung», Strahlentherapie 50 (1934b) 1-78

- Die Vererbung der Krebskrankheit (Berlin 1935)

- «Allgemeine Pathologie der Geschwulstbildung und Geschwulstbekämpfung», in: Auler/ Martius (1941) 11-35

Frets, Gerrit P., «Geneeskundig onderzoek voor het huwelijk», Afkomst en Toekomst 7 (1941) 267-272

Gütt, Arthur/Ernst Rüdin/Falk Ruttke, Gesetz zur Verhütung erbkranken Nachwuchses vom 14. Juli 1933, nebst Ausführungsverordnungen (München ${ }^{2} 1936$ )

Hajema, Luuk, «Ströer was nationaal-socialist uit overtuiging», Universiteitskrant Groningen 22 (October 1987)

Haubold, Helmut, «II. Internationaler Kongress für Krebsforschung und Krebsbekämpfung in Brüssel (20.-26. September 1936)», Zeitschrift für Krebsforschung 44 (1936) 528-539

- «Zur Krebsstatistik. Jahrestagung der Reichsarbeitsgemeinschaft und des Reichsausschusses für Krebsbekämpfung in München», Monatsschrift für Krebsbekämpfung 7 (1939) 309-311

- «Bevölkerungspolitik und Krebs», in: Auler/Martius (1941) 234-246

Jong, Lou de, Het Koninkrijk der Nederlanden in de Tweede Wereldoorlog, Vol. 6, Juli '42-mei '43 (The Hague 1975)

Kater, Michael, Das «Ahnenerbe» der SS 1933-1945. Ein Beitrag zur Kulturpolitik des Dritten Reiches (München ${ }^{2} 1997$ ) 
Klee, Ernst, Das Personallexikon zum Dritten Reich. Wer war was vor und nach 1945 (Frankfurt am Main 2007)

Korteweg, Remmert, «Erfelijkheid bij kanker, in het bijzonder bij kanker van de borstklier», Vlaamsch Geneeskundig Tijdschrift 20 (1939) 61-70, 91-95

- «Kanker», in: Sirks/Kastein (1941) 149-153

Krabben, Anja/Toine Pieters/Stephen Snelders, Kanker ... Als het in de genen zit (Diemen 2007)

Lieburg, Mart van/Wijnand Mijnhardt (Hrsg.), «Geneeskunde en gezondheidszorg in Nederland 1940-1945», Gewina 14 (1991) 175-253

Moser, Gabriele, ««Musterbeispiel forscherischer Gemeinschaftsarbeit?〉 Krebsforschung und die Förderungsstrategien von DFG und Reichsforschungsrat im NS-Staat», Medizinhistorisches Journal 40 (2005) 113-139

- ««Forschungen für die Abwehr biologischer Kriegsmethoden〉 und Krebsforschung im Zweiten Weltkrieg: Die Forschungsarbeiten beim 〈Reichsbevollmächtigten für Krebsforschung〉», in: Eckart, Wolfgang U./Alexander Neumann (Hrsg.), Medizin im Zweiten Weltkrieg: Militärmedizinische Praxis und medizinische Wissenschaft im «Totalen Krieg» (Paderborn 2006a) 131-150

- 'From deputy to 'Reichsbevollmächtigter' and defendant at the Nuremberg medical trials: Dr Kurt Blome and cancer research in National Socialist Germany”, in: Wolfgang U. Eckart (ed.), Man, Medicine and the State: the human body as an object of government sponsored medical research in the 20th century (Stuttgart 2006b) 197-220

Noordman, Jan, Om de kwaliteit van het nageslacht. Eugenetica in Nederland 1900-1950 (Nijmegen 1989)

Proctor, Robert, Racial Hygiene: medicine under the nazis (Cambridge 1988)

- The Nazi War on Cancer (Princeton 1999)

Schalij, Gerrit A., «Arts en volksgezondheid», Volksgezondheid 1 (1941) 3-5

Schellekens, Huub/Rob P. W. Visser, De genetische manipulatie (Amsterdam 1987)

Schinz, Hans R./Franz Buschke, Krebs und Vererbung (Leipzig 1935)

Schrijver, F. «Beschouwingen over het vraagstuk van het geneeskundig onderzoek vóór het huwelijk», Afkomst en Toekomst 7 (1941) 273-285

Sirks, Marius J./Gerrit W. Kastein (Hrsg.), Geneeskunde en erfelijkheid (Lochem 1941)

- /Petrus J. Waardenburg (Hrsg.), Geneeskunde en erfelijkheid (Lochem ${ }^{3} 1949$ )

Snelders, Stephen, «Op weg naar een <Germaansche〉 volksgezondheid. Nationaal-socialisme, erfelijkheidsleer en eugenetica in Nederland 1940-945», Gewina 30 (2007a) 62-74

- "National Socialism, Human Genetics and Eugenics in the Netherlands 1940-1945", in: Hans Hooijmaaijers/Ad Maas (eds), Scientific Research in the Second World War (London: forthcoming 2008)

- /Toine Pieters, «Van degeneratie tot individuele gezondheidsopties. Het maatschappelijk gebruik van erfelijkheidsconcepten in de twintigste eeuw», Gewina 26 (2003) 203-215

- /Frans J. Meijman/Toine Pieters, "Cancer Health Communication in the Netherlands 1910-1950: 'Paternalism or popularization?'”, Medizinhistorisches Journal 41 (2006) 271-289

- /Toine Pieters/Frans J. Meijman, «Medische omgang met erfelijke aspecten van kanker», Nederlands Tijdschrift voor Geneeskunde 151 (2007) 712-715

Veld, Nanno C. K. A. in 't, De zuivering van artsen en advocaten. Een bijdrage tot de geschiedschrijving van de zuivering van het vrije beroep ('s-Gravenhage 1983)

Vries, Philip de, Geschiedenis van het verzet der artsen in Nederland (Haarlem 1949)

Wagner, Gustav/Andrea Mauerberger, Krebsforschung in Deutschland. Vorgeschichte und Geschichte des Deutschen Krebsforschungszentrums (Berlin 1989)

Weindling, Paul Julian, Nazi Medicine and the Nuremberg Trials: from medical war crimes to informed consent (Houndmills 2004)

Wibaut, Florentinus, De betekenis der erfelijkheid voor de geneeskunde (Amsterdam 1940)

Woitke, Ronald, Zur Entwicklung der Krebserfassung, -behandlung und -fürsorge im «Dritten Reich». Die Tätigkeit neu geschaffener staatlicher Organe auf diesem Gebiet in den Jahren von 1933 bis 1945 (Dissertation, Universität Leipzig 1993) 